Brit. J. vener. Dis. (1957), 33, 30.

\title{
LUMBAR PUNCTURE HEADACHE IN RELATION TO SEX, AGE, AND CEREBROSPINAL FLUID FINDINGS* ${ }^{*}$
}

\author{
BY \\ C. B. S. SCHOFIELD \\ From the Department of Venereology, Newcastle General Hospital, Newcastle-upon-Tyne
}

Post-lumbar puncture headaches are recognized as being a hazard in the diagnosis and management of patients suffering from syphilis. Much work has been done in the past, and is still being done, to reduce their incidence. There are certain factors which have a definite influence in reducing the number of headaches after lumbar puncture, the most important being the skill of the operator. Allen (1934) reported a $54 \cdot 5$ per cent. headache rate after failure of the puncture, and only 15.5 per cent. when successful, while the figures of Erskine and Johnson (1938) were 89.1 per cent. and 3.4 per cent. respectively.

The use of a fine-gauge needle similarly reduces the incidence: Redlich, Moore, and Kimbell (1946), using 16- and 22-gauge needles, recorded 60 per cent. and 48 per cent. headaches respectively, and Emory (1948) observed headaches in 41.8 per cent. of patients when a 19-gauge needle was used, the incidence dropping to $27 \cdot 5$ per cent. with a 20 -gauge needle.

If the cerebrospinal fluid is abnormal, there is less chance of headache after lumbar puncture; Nelson (1930) recorded 21.8 per cent. headaches with normal and 10 per cent. with pathological fluids. Several other authors, including Allen (1934) and Erskine and Johnson (1938), have reported similar findings, the only contradictory ones being in a small series by Grewel (1936).

The position of the patient during lumbar puncture would appear to play a part in the incidence of headaches, those lying in the left lateral position having fewer headaches than those sitting up. This was observed by Underwood (1946), whose incidence for lying and sitting up was 17 per cent. and 22 per cent. respectively, and Emory (1948), whose figures were $26 \cdot 8$ per cent. and $41 \cdot 8$ per cent.

Other measures of doubtful value include the use of drugs, Baar (1920) giving intravenous saline after lumbar puncture and Emory (1948) giving 2 g. salt

* Received for publication September 12, 1956.

+ Based on material for M.D. Thesis, University of Durham.
(NaC1) immediately before, and Stürup (1933) inserting an atropine suppository after lumbar puncture.

Rest would not appear to be of any help in lowering the incidence of headaches, according to the findings of Blau (1941), Underwood (1946), and Emory (1948), who found that the longer the rest, the greater the number of headaches. Recently, however, Rosedale (1956), reporting a personal series of 449 lumbar punctures, had a headache rate in male patients under the age of 40 years of $3 \cdot 2$ per cent. with 18 hours of rest, as compared with 26.5 per cent. without rest. Quasi-surgical procedures, such as plugging the wound with cat-gut, as recommended by Nelson (1930) and Emory (1948), are not practical in out-patient clinics.

Dattner (1944) states that headache can be prevented by rest in bed, but only for the time that the patient is lying prone. The incidence can be reduced by the use of fine or double needles, but even then some patients will have postpunctural disturbances even though all precautions are taken. Any theory as to the causation of these headaches must take into consideration the following points:

(1) Headaches are more frequent in patients with normal than pathological fluids. Patients with spinal fluid rhinorrhoea, losing up to 2 litres daily, do not have headaches.

(2) There may be a delay of up to 2 days in the onset of a headache after lumbar puncture.

The causes of post-lumbar puncture headache would appear to be many and varied, and not all the investigators have found an anatomical cause. Blau (1941), Adler (1943), and Redlich and others (1946) found that the headaches were mainly functional in origin.

\section{Present InVestigation}

This investigation reviews the incidence of postlumbar puncture headaches as reported by those patients attending the clinic after diagnostic lumbar 
puncture, and concerns those lumbar punctures done by the medical staff between January, 1945, and July, 1951, either on admission to the clinic and before treatment, or as part of the final tests of "cure" before discharge from the clinic.

\section{TECHNIQUE}

Lumbar puncture is done with the patient sitting on a table, his shoulders supported by the assistant, and the operator sitting on a chair. Local anaesthetic is used, if for no other reason than that the fine needle makes the initial skin puncture and also finds the inter-spinous space. Twenty-gauge Pitkin and Dattner needles are available in all the lumbar puncture kits. A piece of freshly-cut zinc plaster is applied as a dressing and left on for 2 days. The patient can leave the clinic immediately after lumbar puncture if he has no complaints, otherwise he rests on a couch until fit to go home.

The only exceptions to the above technique are young children and some adults who are not considered to be cooperative, e.g., mental defectives. In these cases, puncture is performed in the theatre under general anaesthesia in the right or left lateral position, and the patient rests in the ward until recovered from the anaesthetic.

In the case of in-patients, blocks under the foot of the bed are not allowed unless and until a post-lumbar puncture headache develops, when the patient is kept prone, heavily sedated, and given parenteral ergotamine tartrate.

\section{RESUlts}

In this series of 2,291 lumbar punctures, 148 (6.5 per cent.) headaches were reported to the doctor on the next visit to the clinic (Table I).

\section{TABLE I}

HEADACHE RATES IN ACQUIRED AND CONGENITAL SYPHILIS, MALE AND FEMALE PATIENTS WITH PATHOLOGICAL AND NORMAL FLUIDS

\begin{tabular}{|c|c|c|c|c|c|}
\hline \multirow{2}{*}{$\begin{array}{l}\text { Type of } \\
\text { Syphilis }\end{array}$} & \multirow[b]{2}{*}{ Sex } & \multirow{2}{*}{$\begin{array}{c}\text { Cerebrospinal } \\
\text { Fluid }\end{array}$} & \multirow{2}{*}{$\begin{array}{l}\text { No. of } \\
\text { Patients }\end{array}$} & \multicolumn{2}{|c|}{ Headaches } \\
\hline & & & & Number & $\begin{array}{l}\text { Per } \\
\text { cent. }\end{array}$ \\
\hline \multirow{2}{*}{ Acquired.. } & Male & $\begin{array}{l}\text { Pathological } \\
\text { Normal } \quad .\end{array}$ & $\begin{array}{r}220 \\
1,069\end{array}$ & $\begin{array}{r}5 \\
88\end{array}$ & $\begin{array}{l}2 \cdot 3 \\
8 \cdot 2\end{array}$ \\
\hline & Female & $\begin{array}{l}\text { Pathological } \\
\text { Normal } \quad .\end{array}$ & $\begin{array}{l}107 \\
644\end{array}$ & 51 & $\begin{array}{l}1.9 \\
7.9\end{array}$ \\
\hline \multirow{2}{*}{ Congenital } & Male & $\begin{array}{l}\text { Pathological } \\
\text { Normal } \quad .\end{array}$ & $\begin{array}{r}26 \\
118\end{array}$ & $\begin{array}{l}0 \\
2\end{array}$ & $\overline{1 \cdot 7}$ \\
\hline & Female & $\begin{array}{l}\text { Pathological } \\
\text { Normal .. }\end{array}$ & $\begin{array}{l}20 \\
87\end{array}$ & $\begin{array}{l}0 \\
0\end{array}$ & 二 \\
\hline Totals & . . & .. & 2,291 & 148 & $6 \cdot 5$ \\
\hline
\end{tabular}

Applying the $\chi^{2}$ test to the above figures, no significant difference was found between the total male and female headache rates:

$$
\chi^{2}=0.1 ; n=1 ; P=>0.5
$$

However, the difference between the headache rates of pathological and normal fluids was highly significant :

$$
\chi^{2}=14.6 ; n=1 ; P=<0.001
$$

To ascertain the relationship between the severity of the spinal fluid changes and the headache rate, the spinal fluids were graded, using the method quoted by Stokes, Beerman, and Ingraham (1944) (Table II).

TABLE II

HEADACHE RATES IN ACQUIRED NEUROSYPHILIS, BY GRADING OF CEREBROSPINAL FLUID

\begin{tabular}{c|c|c|c|c}
\hline $\begin{array}{c}\text { Cerebrospinal } \\
\text { Fluid } \\
\text { (grade) }\end{array}$ & Sex & $\begin{array}{c}\text { No. of } \\
\text { Patients }\end{array}$ & \multicolumn{2}{|c}{ Headaches } \\
\cline { 3 - 5 } & I & Mo. & Per cent. \\
\hline II & & 30 & 2 & $6 \cdot 7$ \\
& Female & 30 & 1 & $3 \cdot 3$ \\
\hline III & Male & 128 & 3 & $2 \cdot 3$ \\
& Female & 51 & 1 & $2 \cdot 0$ \\
\hline Totals & Male & 62 & 0 & - \\
\hline
\end{tabular}

The highest headache rate occurred in those patients with acquired syphilis who had normal cerebrospinal fluids (Figure); there were 139

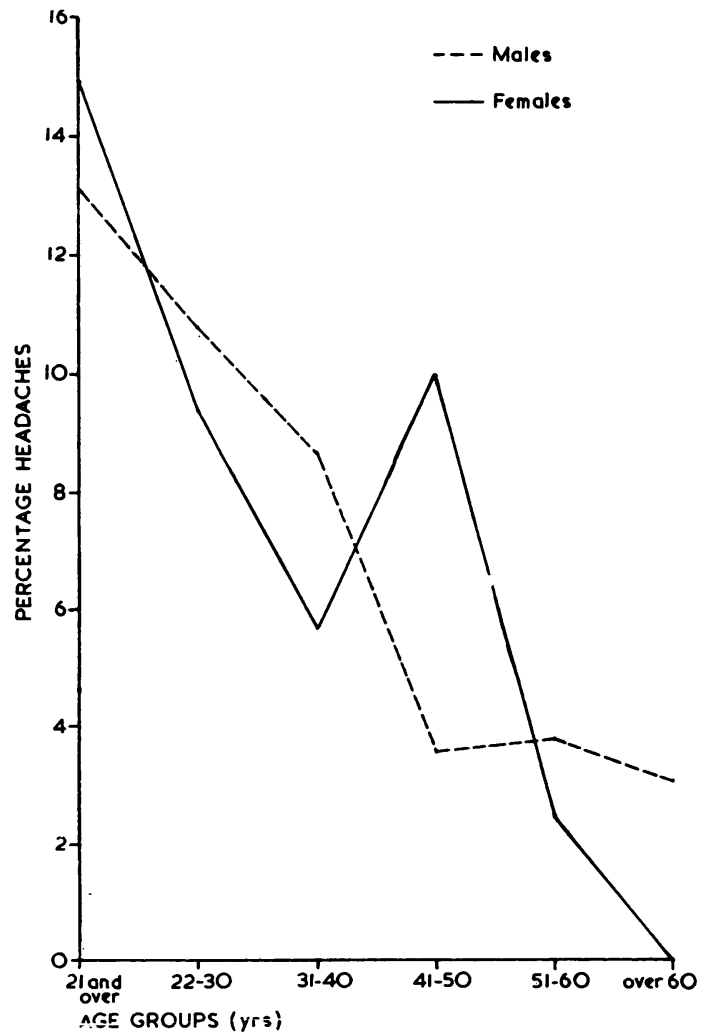

FIGURE.-Headache rates in cases of acquired syphilis with normal cerebro-spinal fluid findings, by age group. 
headaches in this group, the other two headaches occurring in male patients aged 25 and 37 who suffered from congenital syphilis (Table III).

TABLE III

HEADACHE RATES ACCORDING TO AGE OF PATIENTS WITH ACQUIRED SYPHILIS AND NORMAL CEREBROSPINAL FLUIDS

\begin{tabular}{c|r|r|r|r|r|r|r|r|r}
\hline & \multicolumn{3}{|c|}{ Males } & \multicolumn{3}{|c|}{ Females } & \multicolumn{3}{|c|}{ Total } \\
\cline { 2 - 9 } $\begin{array}{c}\text { Age } \\
\text { (yrs) }\end{array}$ & $\begin{array}{r}\text { No. } \\
\text { of } \\
\text { Pa- } \\
\text { tients }\end{array}$ & $\begin{array}{r}\text { Head- } \\
\text { aches }\end{array}$ & $\begin{array}{c}\text { Per } \\
\text { cent. }\end{array}$ & $\begin{array}{r}\text { No. } \\
\text { of } \\
\text { Pa- } \\
\text { tients }\end{array}$ & $\begin{array}{r}\text { Head- } \\
\text { aches }\end{array}$ & $\begin{array}{r}\text { Per } \\
\text { cent. }\end{array}$ & $\begin{array}{r}\text { No. } \\
\text { of } \\
\text { Pa- } \\
\text { tients }\end{array}$ & $\begin{array}{r}\text { Head- } \\
\text { aches }\end{array}$ & $\begin{array}{c}\text { Per } \\
\text { cent. }\end{array}$ \\
\hline-21 & 61 & 8 & $13 \cdot 1$ & 47 & 7 & $14 \cdot 9$ & 108 & 15 & $13 \cdot 7$ \\
$22-30$ & 434 & 47 & $10 \cdot 8$ & 223 & 21 & $9 \cdot 4$ & 657 & 68 & $10 \cdot 3$ \\
$31-40$ & 242 & 21 & $8 \cdot 7$ & 176 & 10 & $5 \cdot 7$ & 418 & 31 & $7 \cdot 4$ \\
$41-50$ & 168 & 6 & $3 \cdot 6$ & 110 & 11 & $10 \cdot 0$ & 278 & 17 & $6 \cdot 2$ \\
$51-60$ & 132 & 5 & $3 \cdot 8$ & 79 & 2 & $2 \cdot 5$ & 211 & 7 & $3 \cdot 3$ \\
$61+$ & 32 & 1 & $3 \cdot 1$ & 9 & 0 & - & 41 & 1 & $2 \cdot 4$ \\
\hline Totals & 1,069 & 88 & $8 \cdot 2$ & 644 & 51 & $7 \cdot 9$ & 1,713 & 139 & $8 \cdot 1$ \\
\hline
\end{tabular}

In Table III there is no significant difference in headache rate between the total males and females $\left(\chi^{2}=0.02 ; n=1 ; P=>0.8\right)$, nor in the age groups, except in the fifth decade, when the difference is significant: $\chi^{2}=3.7 ; n=1 ; P=0.05$.

Examining the combined male and female headache rate in relation to age, there is a high degree of negative correlation. Omitting the extreme age groups, and taking the mean age in the other four groups, the following formula is applied:

$$
r=\frac{\frac{1}{N} \sum u v-\bar{u} \bar{v}}{\sigma_{u} \sigma_{v}}
$$

For these groups the coefficient of correlation $r=-0.98$. In other words, the headache rate falls almost exactly in proportion to the increase in age.

\section{Discussion}

While the reduced incidence of post-lumbar puncture headaches in active neurosyphilis in inverse proportion to the severity of the cerebrospinal fluid findings is in agreement with the findings of other authors, the low overall incidence $(6.5$ per cent.) is deserving of comment. We believe that the general low incidence of headaches is due, in the main, to the experience of the staff, the operators, and their assistants. It is a rule in the department that an operator has one attempt only at a lumbar puncture; if he fails he does not traumatize the area with further attempts, but he withdraws the needle and the patient is sent home. A repeat lumbar puncture can be done on the next visit, the explanation to the patient being that the laboratory requires confirmation of the previous findings. In the case of repcated failure the patient is $x$-rayed with a suitable "marker" alongside the vertebral column, and in this way a space may be found. Patients are not warned that a lumbar puncture is to be done on a following visit, but are only told at the time. The puncture is done without fuss, being treated as no more than a blood test. Last, but not least, the equipment for lumbar puncture is kept in first-class condition. Lumbar puncture kits, after use, are cleaned, then examined to make sure that the needles and stilettes are sharp and fitting correctly. If not, they are sharpened in the department before the kit is reassembled and autoclaved.

The decline in post-lumbar puncture headaches with increasing age observed in those patients with normal cerebrospinal fluids, is similar to reports by anaesthetists, although their series may not be strictly comparable with those of venerologists in that they are introducing various foreign materials intrathecally. Previously unreported, however, is the definite and significant rise in the headache rate for women in the fifth decade, coincident with the menopause. This gives further support to the belief that there is a large functional element in the causation of post-lumbar puncture headaches.

The close similarity between the incidence of headaches in males and females in this investigation is contrary to the usual female preponderance, and for this there is no apparent reason, except that by only making one attempt at one time we endeavour to reduce the trauma and discomfort to the female patients, some of whom have quite a deep layer of lumbo-sacral fat which makes identification of the bony landmarks difficult. It is in these cases that the use of the local anaesthetic needle is of such value in finding the spaces between the spines.

Default after lumbar puncture is an uncommon occurrence in our department, but fear of lumbar puncture caused by "waiting-room gossip" does cause some default. It is strange that the majority of the gossipers, when tracked down, have not had headaches themselves but say that they have heard of others who have had a bad time.

In view of our low headache rate we have not adopted the left lateral position, which is reported as being associated with a lower incidence of headaches. The sitting-up technique is preferred because it is more comfortable for the operator who sits on a chair, and the patient, who sits on a table, feels less confined than in the left lateral position with his chin on his knees. Furthermore with the patient sitting up it is easier to adjust the back to keep it vertical, or to make allowance for any scoliosis, than with the patient lying on his side.

\section{Conclusions}

With experienced operators using first-class equipment, the fear of causing post-lumbar puncture 
headaches need not be a deterrent in performing diagnostic lumbar punctures. Default after these headaches is negligible.

Confirmation of a large functional element in the causation of these headaches is suggested by comparing sex and age distribution and noting the rise in incidence at the menopause.

It is believed that, until lumbar puncture is regarded as a routine measure and not as a major operative procedure, stories of the most lurid nature will continue to be spread, deterring both doctor and patient from its necessary performance. Failures to obtain cerebrospinal fluid and magnification of the hazards are mainly caused by faulty technique, incorrect posture of the patient, and the use of unsatisfactory needles.

\section{SUMMARY}

In a series of 2,291 diagnostic lumbar punctures, performed during a period of $6 \frac{1}{2}$ years, headaches, believed genuine, were subsequently reported to the doctor on $148(6.5$ per cent.) occasions. The incidence was 6.6 per cent. for males and 6.2 per cent. for females.
The incidence was higher in acquired $(7 \cdot 2$ per cent.) than in congenital syphilis ( 0.8 per cent.), and with normal $(7 \cdot 3$ per cent.) than with pathological fluids ( 1.8 per cent.), varying, in the latter, in inverse proportion to the severity of the cerebrospinal fluid findings. In patients suffering from acquired syphilis and having normal fluids, the incidence of headaches dropped with increasing age, except for a definite rise in females at the menopause, confirming the strong functional element in the causation of post-lumbar puncture headaches.

\section{REFERENCES}

Adler, H. (1943). N.Y. St. J. Med., 43, 1328.

Allen, H. W (1934) Brit. med. J., $2,349$.

Baar, G. (1920). Med. Rec. (N.Y.), 98, 598.

Blau, A. (1941). Urol. cutan. Rev., 45, 239.

Dattner, B. (1944). "The Management of Neurosyphilis", p. 33. Heinemann, London.

Emory, M. L. (1948). Amer. Practit. (Philad.), 2, 451.

Erskine, D., and Johnson, A. G. (1938). Lancet, 2, 371.

Grewel, F." (1936). Ned. T. Geneesk., 80, 3946.

Nelson, M. O. (1930). Arch. Derm. Syph. (Chicago), 21, 615.

Redlich, F. C., Moore, B. E., and Kimbell, I. (1946). Psychosom. Med., 8, 386

Rosedale, N. (1956). British Journal of Venereal Diseases, 32, 127.

Stokes, J. H., Beerman, H., and Ingraham, N. R. Jr. (1944) "Modern Clinical Syphilology", 3rd ed., p. 120. Saunders, Philadelphia.

Stürup, G. (1933). Acta psychiat. neurol. scand. 8, 181

Underwood, L. J. (1946). Amer. J. Syph., 30, 264. 